\title{
THE IMPLEMENTATION OF 2013 CURRICULUM AT SMA NEGERI 12 PEKANBARU
}

\author{
Sri Yuliani \\ Islamic University of Riau \\ email: sriyuliani@edu.uir.ac.id
}

\begin{abstract}
The aim of the research was to find out teaching and learning activities at SMA Negeri 12 in implementing 2013 curriculum. This research was based on the preliminary studies in some Junior and Senior High Schools around Pekanbaru by observing and interviewing the English teacher in excuting 2013 curriculum. The design of this Research was qualitative.The researcher used observation sheet and interview to find out the activities in SMA Negeri 12. Based on the research findings, first, the stage of teaching and learning process in the classroom, the teacher could not implement the step ideally, second, the professional curriculum from the government did not provide the available training to support teaching and learning in the classroom and the last the availability of resources and media were not supported yet. By conducting this research, the researcher hoped that the government conducting the appropriate training to all English teachers in implementing 2013 curriculum.
\end{abstract}

Keywords: Implementation, Curriculum, Training

\section{IMPLEMENTASI KURIKULUM 2013 DI SMA NEGERI 12 PEKANBARU}

\begin{abstract}
Abstrak
Tujuan dari penelitian ini adalah untuk mengetahui kegiatan belajar mengajar di SMA Negeri 12 dalam melaksanakan kurikulum 2013. Penelitian ini didasarkan pada studi pendahuluan di beberapa SMP dan SMA di sekitar Pekanbaru dengan mengamati dan mewawancarai guru bahasa Inggris dalam pengimplemetasian kurikulum 2013. Desain Penelitian ini adalah qualitative. Peneliti menggunakan lembar observasi dan wawancara untuk mengetahui kegiatan di SMA Negeri 12. Berdasarkan temuan penelitian, pertama, tahap proses belajar mengajar di kelas, guru belum bisa melaksanakan langkah pengajaran secara ideal, kedua, secara profesional, pelaksana kurikulum belum mendapatkan pelatihan dari pemerintah untuk mendukung proses belajar mengajar di kelas dan yang terakhir ketersediaan sumber daya dan media yang belum didukung. Dengan melakukan penelitian ini, peneliti berharap bahwa pemerintah melakukan pelatihan yang tepat untuk semua guru bahasa Inggris dalam menerapkan kurikulum 2013.
\end{abstract}

Kata Kunci : Implementasi, Kurikulum, Pelatihan 


\section{INTRODUCTION}

Education curriculum in Indonesia has been changed for several times. Government made changes and improvements to the curriculum to adapt for the development and the changing of advance technology in the world competition. With the changing of curriculum, it is expected to fulfill the objectives and goals of education in Indonesia.

At the year of 2013, Indonesia had changed the curriculum with an integrative thematic concept which applied to elementary, junior high school, senior high school, and vocational school. The reason why this thematic concepts added in new curriculum because it hopes that with the changing of curriculum the students in Indonesia will face the competitive advance technology in the world are maximally prepared.

To change and implement a new curriculum is not an easy task. There are many barriers to the successful implementation of a curriculum. First, many parties will resist with this changing. Second, the trial will take times. The last, the successfulness of implementation new curriculum will not full guarantee.

In this case, the researcher focused on the successfulness of implementation of 2013 curriculum in term of all process of teaching and learning in the classroom to fulfill all the requirements in the new curriculum. Based on the researcher observations and interviews to English teacher at SMA Negeri 12 Pekanbaru, One of the English Teacher in SMA N 12 , he was confused how to implement the 2013 curriculum with the appropriate way.

The preparation from government in implementing the new 2013 curriculum to the English teachers in Indonesia seemed unprepared yet. The government forced their decisions to implement new curriculum without well arrangement and without appropriate training to the teachers. In SMA Negeri 12 Pekanbaru as one of the chosen schools to implement this new curriculum, One of the English Teacher in SMA N 12 said that he was not quite prepare with this new curriculum. Actually, he needed more guidance from the counselors to guide him to implement the new curriculum but it seemed that the counselors also did not understand what should they did, at last one of the English Teacher in SMA N 12 became more confused with this situation.

\section{METHOD}

This research is qualitative design. The instruments of this research were observation sheet and interview.

\section{a. Observation}

The observation sheet was designed based on the standardized guidelines Observation was used to know more about the quality, facilities, materials, and the appropriate training in applying 2013 Curriculum in the chosen school. The items which were being adapted in implementing this new curriculum was based on the Curriculum Implementation Observation sheet in at table 1: 
Table 1: The Curriculum Implementation Observation

\begin{tabular}{|c|c|}
\hline Factors & Description \\
\hline Adequacy of resources & $\begin{array}{l}\text { Adequacy of equipment, facilities and general } \\
\text { resources required for implementing a new } \\
\text { curriculum }\end{array}$ \\
\hline Time & $\begin{array}{l}\text { Time available for preparing and delivering the } \\
\text { requirements of the new curriculum. e.g. teachers } \\
\text { need enough time to develop their own } \\
\text { understanding of the subject they are required to } \\
\text { teach. }\end{array}$ \\
\hline School ethos & $\begin{array}{l}\text { Overall school beliefs towards the new } \\
\text { curriculum. Status of the curriculum as viewed by } \\
\text { staff, administrators and community. }\end{array}$ \\
\hline Professional support & $\begin{array}{l}\text { Support for teachers from both within the school } \\
\text { and outside. e.g. opportunities to receive ongoing } \\
\text { curriculum professional support }\end{array}$ \\
\hline Professional adequacy & $\begin{array}{l}\text { Teachers' own ability and competence to teach } \\
\text { the curriculum. i.e. confidence in teaching }\end{array}$ \\
\hline Professional knowledge & $\begin{array}{l}\text { Knowledge and understandings teachers possess } \\
\text { regarding the new curriculum. e.g. different ways } \\
\text { of teaching to foster student learning. }\end{array}$ \\
\hline $\begin{array}{c}\text { Professional attitude and } \\
\text { Interest }\end{array}$ & $\begin{array}{l}\text { Attitudes and interest of teachers toward the new } \\
\text { curriculum e.g. keen to teach the subject }\end{array}$ \\
\hline
\end{tabular}

[source: adapted from the Science Curriculum Implementation Observation (SCIO). http://home.cc.umanitoba.ca/ lewthwai/introSCIQ.html].

b. Interview

Interview was used firstly to get information directly from head of school, then interview was used at the

\section{FINDINGS AND DISCUSSION}

The findings and intrepretation of this part were mainly concerned with the implementation of 2013 curriculum. There were some items were necessary to be discussed below: observation stage. The last, at the implementation stage, interview was done to get the activity process of teaching and learning in the classroom.

\section{a. The ways English teachers at SMA Negeri 12 Pekanbaru implement 2013 curriculum. \\ 1) Preparing Students Materials \\ In the classroom observation conducted by the researcher to know}


the way English teacher at SMA Negeri 12 Pekanbaru prepared his students material, the teacher was preparing his topic at home before entering the classroom. When preparing the materials to the students, he used to considered about student's interest. He chose the material based on the topic in the syllabus of 2013 curriculum. He said that the materials were not from the textbook but he got it from internet, news research, and other source which could support his material in teaching. During his teaching by using this new 2013 curriculum, he did not get the textbook yet. He tried to find the textbook from the publisher like Airlangga, Yudhistira, and some modules from Cemerlang but the content did not suit the syllabus in 2013 curriculum. In this matter, he said that he became more active and more creative in developing the materials, it was one advantages in using this 2013 curriculum.

When the researcher observed English teacher in the classroom, the topic was about the "announcement". In 2013 curriculum stated in the topic column is written text in form of announcement. The function was to give information with or without instructions or clues which should be followed, to smooth the information between teacher, student, headmaster, and administration staff.

The text structure was to express announcement text in mass media, internet as a whole part or sequence. The language feature was vocabularies, grammar, pronunciation, references, intonation and stress, which pronounced fluently. And the last, multimedia was about the layout and decoration which purpose to make the beautiful views.

First, the teacher distributed the materials to the students, then after finishing distribution he asked the students to listen to him how to read the text. Then, the students listened to the teacher how to read the text. After finishing reading, the teacher asked the students read loudly alone at their seats. Next, not more than 5 minutes, the teacher instructed some students to read the text in front of the classroom.

Based on this observation, the teacher was already followed the instruction from the syllabus in 2013 curriculum stated that the material was from internet, the language feature was vocabularies, grammar, pronunciation, references, intonation and stress, which pronounced fluently.

\section{2) Using Media}

When the researcher observed his teaching in the classroom, the teacher used pictures of announcement. The layout of the picture was interesting. Besides pictures, he also used his laptop to show the text, LCD, and he said sometimes he also brought his students to language laboratory.

In using the language laboratory, he should follow the schedule which has been prepared by the laboratory coordinator. There were 14 classes which had been arranged. There were 6 times to use the language laboratory based on his schedule because he taught all $\mathrm{X}$ classes in SMA Negeri 12 Pekanbaru.

\section{3) Classroom Activity}

Based on 2013 curriculum, the classroom activity consisted on five parts, first was observing, second was 
questioning, third was exploring, fourth was associating, and the last was communicating.

When the researcher observed the activity of teacher in his classroom, he started the class by saying greeting and rolled absenteeism, after that he distributed his materials to his students. Every student got one research, then, he turned on his laptop and connected to the LCD. After the laptop connected to LCD, he instructed his students to observe his reading. In this part, the activities of observing the students were listening to the teacher, then they tried to imitate the teacher's pronunciation, and tried to get the main idea of the text. After finishing reading, the teacher appointed some students to read loudly in front of the classroom.

After that, the teacher asked some simple questions to the students to make students rethink about what topic which had been read. This activity suited with the criteria of questioning in part of 2013 curriculum.

In part of exploring, the students were difficult to find another source to be read. It was because no computers available in classroom. In 2013 curriculum stated that students tried to find another source material to be read. The materials were taken in the internet or other source, while the equipments were not supported. Here, in part of exploring based on the researcher's observation seemed that students were difficult to explore more materials because shortage of equipments.

In part of associating, the students were asked to analyze the text by observing the type of grammar and type of writing. The teacher divided the students into six groups and instructed them to analyze the text which had been given. The last, the teacher instructed them to compose one announcement in group. In this part, the students did not enrich by many sources, they became bored and confused what to do while textbook were not available yet just waited the material from the teacher.

In part of communicating, the students presented their text about announcement in group. One student represented his/her group work to the other group. This activity took turn among groups. With the same sources, every group presented the topics repeatedly. It made them felt monotonous.

\section{4) Classroom Management}

In managing the classroom, based on the researcher's observation was that the teacher tried his effort to create the class with good atmosphere for students to study. He arranged the students' chair by group of six, the purpose to make the students were not bored. Then after finishing a group work, the teacher asked the students to adjust the chairs like previously.

\section{b. The Problems faced by English Teacher in Implementing 2013 curriculum at SMA Negeri 12 Pekanbaru}

\section{1) The Problems in Preparing Students Materials}

Based on the observation in the classroom, the researcher saw that in preparing the students' materials in the classroom, the teacher should prepare the materials earlier before entering the classroom. The teacher searched 
materials in the internet and other resources from news research and also magazine. The materials searched by the teacher were relevant to the topics which he would like to perform in the classroom.

During the observation, the researcher observed that no textbook at all. The teacher prepared the materials by himself. But sometimes, if he did not have time to find the materials in the internet or in the news research and magazines, he just use adjusted the materials by his experiences and opinions.

It seemed that the teacher got problem in preparing the students' materials. Sometimes, the materials were also not support the real situation based on the demands of the students in preparing them to be students in the university. This problem also supported by interviewing the teacher himself. He was hard to find the relevant materials to support students with the real life demands in environment both in society surrounding and the future plan in university situation.

\section{2) The Problems in Using Media}

During the observation in the classroom, the researcher observed that the teacher used laptop and LCD in his teaching and sometimes he brought his students in the laboratory. The schedule in laboratory was arranged based on the total numbers of classes. There were 6 times to use the language laboratory based on his schedule because he taught all $\mathrm{X}$ classes in SMA Negeri 12 Pekanbaru.

During the interview between the teacher and the researcher, the teacher mentioned that sometimes the laboratory headsets were not function well, because some students destroyed the cable from the headset and it caused some annoyance during using the laboratory. So, the students were asked by the teacher to sit together to other friends by using one headset in turn. The limitation of media sometimes made the teaching and learning process did not run well.

The advanced technology but the shortage of media made the process of gaining the new knowledge became fail, while the 2013 curriculum asked both students and teachers were familiar with the technology to prepare the students to be a skilful human resources. It seemed that the problems appeared made the process in implementing the 2013 curriculum should be adjusted by the real conditions of each school in Indonesia.

\section{3) The Problems in Classroom Activities}

The activities during the researcher's observation, the teacher held the class well. He started by saying greeting and then rolled the attendance list. $\mathrm{He}$ continued his teaching and learning process well from beginning until the end the class.

The teacher used the media to make students enthusiasm to follow his process of teaching and learning. He made some groups discussion to discuss the materials and then continued with rising some questions from one group to other groups related the materials discussed.

Then, he continued instructed the students to present the topics in each group based on the topic the 
students got. While in the middle of teaching and learning process, the researcher saw some students talked a lot with their partners and it seemed that they talked about their own problems. Based on the observation from the researcher, it assumed that the activities so monotonous that made students felt bored.

\section{4) The Problems in Managing Classroom}

The arrangement of chairs had been arranged based on the normal arrangement. It was lecturing style that in front of the classroom placed the teachers' chair and in front of the teachers' chair were students' chairs.

In the middle of the teaching and learning process, the teacher instructed the students to sit in pairs having small conversation. The researcher observed that this was one of the teacher effort to make the atmosphere was not bored.

There was problem when the teachers instructed the students to make a new arrangement of chairs, it was related to time. In doing the new chairs arrangement, at least the students should change the chairs and sometimes the students walked around here and there and sometimes the students played around with their friends.

\section{c. The Causes of the Problems Encountered by English Teacher in Implementing 2013 curriculum at SMA Negeri 12 Pekanbaru}
1) The Causes of encountered Problems in Preparing Students Materials

The causes encountered during the preparation of students' materials based on the observation from the researcher during teaching and learning process was lack of materials provided by the teacher to find the relevant materials to support students with students' need and the overview of university's situation.

The teacher was lack of time to find the relevant materials related to 2013 curriculum. He was quite busy to find the relevant materials in the internet, news research or magazines.

Another cause was varieties of materials provided by teacher to students. The materials were monotonous that caused the students bored. The real situation materials also were not support well, so it made students felt that they got just general English not specific needs for the students and their future plans.

2) The Causes of Problems Encountered in Using Media The causes problems encountered in using media, based on the researcher observation mostly by lack of time and opportunity to arrange the schedule of using laboratory. The schedule arrangement had been scheduled by the laboratory coordinator, but sometimes the schedule could be changed because some additional classes proposed to third grade.

Another cause problems encountered in using media was the electricity was off. During teaching and learning in the classroom, the researcher observed that when the teacher used laptop to show Video, unfortunately, the electricity was off. It was a problem.

The Implementation of 2013 Curriculum at SMA Negeri 12 Pekanbaru 


\section{3) The Causes of Problems Encountered in Classroom Activities}

The causes of problems encountered in classroom activities, based on the researcher observation that the activities sometimes monotonous and the teacher confused to find the varieties of activities in the classroom. Actually, the teacher could find some strategies to be given to students. By plotting the same activities seemed that the students sometimes sleepy.

Another cause was the limited time to create new strategies, if the teacher wanted to develop more, the time consumed more than it was, then it disturbed the next schedule of teaching and learning.

4) The Causes of Problems Encountered in Managing Classroom

The cause of problems encountered in managing the classroom was mostly the time allocation. While changing the new format of chairs, sometimes took more time rather than when the chairs set previously.

\section{d. The Problems Solving Conducted by English Teacher in Implementing 2013 curriculum at SMA Negeri 12 Pekanbaru}

Even though the English teacher at SMA Negeri 12 Pekanbaru was trying against the problems and the difficulties in implementing 2013 curriculum in the process of teaching and learning, he still made an effort to implement this new curriculum. He had his own way to overcome the problems encountered.

1) The Discussion in Interview Activity

The following description was based on the result of interview with the English teacher at SMA negeri 12 Pekanbaru. Some aspects were asked by the researcher namely; the preparation of teaching materials, media, classroom management, enrichment of vacabularies, and students' motivation and attention.

In term of materials, the teacher had tried to find the materials relevant to the 2013 curriculum, but in fact sometimes the materials did not support the syllabus mentioned. The contents of materials were still general, all sections (IPA, IPS) class provided by the same syllabus. It meant that the content of the materials did not support the needs of demand for students and the demands of university's needs. In this case, the teacher had tried to follow the syllabus of 2013 curriculum well. He tried his effort to find the relevant materials to be presented in the classroom.

In term of media, the teacher had tried his best by finding another supporting media. To replace the mismatch in using laboratory, he tried to use tape recorder. If the electricity was he would replace it with drawing picture in the whiteboard. He already tried his best to implement 2013 curriculum. While, those broken equipments in the laboratory, the teacher reported to the vice headmaster who was handled the schools' equipments to repair the tools 
inside the laboratory as soon as possible.

In term of classroom management, the teacher set the rule at the beginning of new semester. Those students who always played around should get punishment. The students should sit based on the teacher's instruction, if there were some changes, so students should follow the instruction immediately without walking here and there.

In term of vocabularies, the teacher had tried his best by asking the students to read more at home by giving some homework related to vocabularies concerned. For example by giving the similar meaning of the vocabulary or the antonym of the words and the teacher also asked students to underline the difficult words in the texts, then the students consulted to the dictionary. He also asked students to find new terms to be found in the newsresearch or in magazine. Moreover, he also asked students to have chatting with the teacher in the internet by seeing who the active students in replying his comment by using English.

In term of students' attention and motivation, the teacher had tried his best to modify his class to be a comfortable atmosphere. He tried to take students' attention by singing and playing some games. He also tried to combine various teaching technique to increase the student's attention and motivation.

2) The Summary of Observation and Interview Activity

Based on the observation and interview with the teacher at SMA Negeri 12 Pekanbaru, the researcher can describe it in the following table:

\begin{tabular}{|c|c|c|c|}
\hline No & Problems & Causes of the Problem & $\begin{array}{c}\text { The Way to Solve } \\
\text { the Problem }\end{array}$ \\
\hline 1 & Materials & $\begin{array}{l}\text { Did not support the } \\
\text { students' need }\end{array}$ & $\begin{array}{l}\text { To find more relevant } \\
\text { sources to support the } \\
\text { real situation and to } \\
\text { find the students' } \\
\text { need and the market } \\
\text { demand in public. }\end{array}$ \\
\hline 2 & Media & $\begin{array}{l}\text { Electricity and the } \\
\text { broken equipments }\end{array}$ & $\begin{array}{l}\text { To prepare another } \\
\text { source of electricity } \\
\text { like generator. The } \\
\text { rules should be set in } \\
\text { the laboratory with } \\
\text { the fine. }\end{array}$ \\
\hline 3 & Monotonous & $\begin{array}{c}\text { Lack of teaching } \\
\text { variation }\end{array}$ & $\begin{array}{l}\text { To create the relax } \\
\text { atmosphere in the } \\
\text { classroom by } \\
\text { providing many } \\
\text { teaching variations. }\end{array}$ \\
\hline 4 & Playing around & $\begin{array}{c}\text { Lack of classroom } \\
\text { management }\end{array}$ & $\begin{array}{l}\text { To prepare the rules } \\
\text { in the beginning of }\end{array}$ \\
\hline
\end{tabular}




\begin{tabular}{|c|c|c|c|}
\hline | & & & $\begin{array}{c}\text { the semester. The } \\
\text { students may get } \\
\text { punishment if they } \\
\text { break the rules. }\end{array}$ \\
\hline 5 & $\begin{array}{c}\text { Student's less attention } \\
\text { and motivation }\end{array}$ & $\begin{array}{c}\text { To create the } \\
\text { Lack of motivation idea to } \\
\text { enthusiasm } \\
\text { change the situation, } \\
\text { the solution may be } \\
\text { like a present to } \\
\text { award the students' } \\
\text { success. }\end{array}$ \\
\hline 6 & Time Allocation & $\begin{array}{c}\text { Many activities spend in } \\
\text { the classroom process }\end{array}$ & $\begin{array}{c}\text { To manage the time } \\
\text { outside school } \\
\text { activities. }\end{array}$ \\
\hline
\end{tabular}

Based on the data above, the researcher made some conclusion and suggestion in the following part by giving some alternative and option to be done to solve the problem in teaching and learning process in implementing 2013 curriculum. The interviews between the researcher and English teacher at SMA Negeri 12 were supported by the statement proposed by Harvey.,et.al (1990) that:

a. Someone will resist if he/she does not understand. Someone who does not understand will get confuse and try to neglect with the requirement inside the curriculum.

b. Someone will resist if he/she does not have the competencies to cope with the changes. The changes in curriculum need more competencies inside it. For instances, Curriculum 2013 needs human resources (teachers and all parties involved in it) get more competencies in technology. c. Someone will resist if he/she does not have much time to engage with the change. Teachers find it difficult having to juggle between bringing about change handling their current responsibilities. Focusing their energy on change activities, may run the risk of neglecting their current responsibilities.

(Harvey, 1990; Woldring, 1999; Lippitt, 1966)

\section{CONCLUSION}

The research has successfully done to know the way English teacher at SMA Negeri 12 Pekanbaru implement the new curriculum or 2013 curriculum. The problems and the causes of the problems that the teacher encountered in implementing and also the way the teacher overcame the problems the teacher encountered. The conclusion of the research is presented as follow: 
In conducting the stage of teaching and learning process in the classroom, the teacher could not implement the step ideally. For instances, some stages of sequences steps in teaching and learning were mixed or jumped to the other steps.

In developing the materials, the problem was the manual textbook did not provided yet in the public market, so the teacher could not develop the materials well. Moreover, the professional curriculum from the government did not provide the available training to support teaching and learning in the classroom. The contents of topics in the syllabus did not support the needs of students and the market demands.

The use of media was also problem in implementing 2013 curriculum which the curriculum mentioned that the purpose of new 2013 curriculum to increase the advance technology awareness. In fact, the media still far from the expected.

The other problem was the classroom management. Sometimes, some students were bored and sleepy. It seemed that the teacher should provide more varieties in teaching.

Based on the result of the research about the implementation of 2013 curriculum at SMA Negeri 12 Pekanbaru, the implication still got several problems such as the teacher could not use full English in teaching and learning in the classroom, while the requirement of the new curriculum stated that in modern situation English was used to communicate in social function. Moreover, the availability of resources and media were not supported yet. While, in the new 2013 curriculum stated that the use of advance technology was to prepare students to be a competence students. In term of materials, the contents of syllabus as a guidance for teacher were still not fulfill the needs of students and the demands of market.

The cooperation between national education in Riau Province and SMA Negeri 12 Pekanbaru is really needed to equip each classroom and language laboratory with complete facilities for teacher to teach so the teacher do not need to take turns in using the language laboratory. Besides that, the school must conduct small workshop through MGMP program routinely as the place for English teachers share their ideas and knowledge in implementing 2013 curriculum.

Related to the findings and discussion of this research, there are some suggestion related to the implication of 2013 curriculum in the future:

a. The English teachers of SMA Negeri 12 Pekanbaru should learn more about how to implement 2013 curriculum in teaching English subject and they have to know more for the needs of students and the needs of market demands in society.

b. It is better for the headmaster of SMA Negeri 12 Pekanbaru to equip the teaching facilities to support the successfulness of teaching and learning process in the classroom.

c. It is suggested for the chief of educational department in Riau

The Implementation of 2013 Curriculum at SMA Negeri 12 Pekanbaru 
Province to conduct more training in implementation of this new 2013 curriculum for all teachers in Pekanbaru.

d. There should be more research conducted in order to investigate the English teachers' preparation and evaluation of the implementation 2013 curriculum for longer period to obtain more accurate data.

\section{REFERENCES}

Baker, E.L. \& O’Neil Jr, H.F. (1994).

Performance assessment and equity: A view from the USA. Assessment in Education, 1(1), 11-26.

Fook, C.Y. \& Sidhu, G.K. (2010). Authentic Assessment and Pedagogical Strategies in Higher Education. Journal of Social Sciences, 6(2), 153-161.

Kirst, M. (1991). Interview on assessment issues with Lorrie Shepard. Educational Paperer, 20(2), 21-23, 27.

Harvey.,et.al. (1990). Curriculum Resistance. Journal of Curriculum, 10(1), 115-135.

Mueller, J. (2005). The Authentic Assessment Toolbox: Enhancing Student Learning through Online Faculty Development. Journal of
Online Learning and Teaching, 1(1), 1-7.

Newmann, F.M. (1997). Authentic assessment in social studies: Standards and examples. In G.D. Phye (Ed.), Handbook of classroom assessment: Learning, adjustment and achievement. San Diego, Ca: Academic Press.

Pellegrino, J.W., Chudowsky, N. \& Glaser, R. (2001). Knowing What Students Know: The Science and Design of Educational Assessment. National Academies Press, Washington, DC., USA.

Schack, G.D. (1994). Authentic assessment procedures for secondary students' original paper. The Journal of Secondary Gifted Education, 6(1), 38-43.

Strevens, P. (1977a). New Orientations in the Teaching of English. Oxford: Oxford University Press.

Strevens, P. (1977b). Language Teaching and Linguistics: Abstracts. Cambridge: Cambridge University Press.

Strevens, P. (1988). ESP after twenty years: A re-appraisal. In $M$. Tickoo (Ed.), ESP: State of the Art, (pp. 1 - 13). Singapore, SEAMEO Regional Language Centre. 